\title{
Re-Inventing Existing Real Estate of Social Housing for Older People: Building a New De Benring in Voorst, The Netherlands
}

\author{
Joost van Hoof ${ }^{1,2, *(\mathbb{D})}$ and Peter Boerenfijn ${ }^{3,4}$ \\ 1 Faculty of Social Work \& Education, The Hague University of Applied Sciences, Johanna Westerdijkplein 75, \\ 2521 EN Den Haag, The Netherlands \\ 2 Department of Spatial Economy, Faculty of Environmental Engineering and Geodesy, Wrocław University of \\ Environmental and Life Sciences, ul. Grunwaldzka 55, 50-357 Wrocław, Poland \\ 3 Habion, Parijsboulevard 143 G, 3541 CS Utrecht, The Netherlands; p.boerenfijn@habion.nl \\ 4 Vastgoed Zorgsector, Parijsboulevard 143 G, 3541 CS Utrecht, The Netherlands \\ * Correspondence: j.vanhoof@hhs.nl; Tel.: +31-6-23381404
}

Received: 20 June 2018; Accepted: 4 July 2018; Published: 5 July 2018

\begin{abstract}
Population ageing has become a domain of international discussions and research throughout the spectrum of disciplines including housing, urban planning, and real estate. Older people are encouraged to continue living in their homes in their familiar environment, and this is referred to as "ageing-in-place". Enabling one to age-in-place requires new housing arrangements that facilitate and enable older adults to live comfortably into old age, preferably with others. Innovative examples are provided from a Dutch social housing association, illustrating a new approach to environmental design that focuses more on building new communities in conjunction with the building itself, as opposed to the occupational therapeutic approaches and environmental support. Transformation projects, referred to as "Second Youth Experiments", are conducted using the Røring method, which is based on the principles of co-creation. De Benring in Voorst, The Netherlands, is provided as a case study of an innovative transformation project. This project shows how social and technological innovations can be integrated in the retrofitting of existing real estate for older people. It leads to a flexible use of the real estate, which makes the building system- and customer preference proof.
\end{abstract}

Keywords: real estate; housing; elderly; social housing; retrofitting; health care

\section{Introduction}

The ageing of society has been a focus of research since the 1960s [1], and the population ageing has become a domain of international discussions and research throughout the spectrum of disciplines including housing, urban planning, and real estate [2-6]. The ageing population has a profound impact on the real estate market, which is, for instance, transforming in terms of the availability of single-floor dwellings for older people [7]. Older people usually have a strong connection with the environment they know well [8], enabling them to spend the latter years of their life in a familiar setting, which, in turn, influences their independence. Older people are encouraged to continue living in their homes in their familiar environment, instead of moving to an institutional care facility, and this is referred to as "ageing-in-place" [9]. In the domain of environmental design, a series of home modifications can be identified to support older people. The most frequently encountered measures in and around the home are adaptations to improve the accessibility of the home (i.e., removal of barriers such as thresholds, installation of stair lifts in multi-storey homes, and the replacement of bath tubs by walk-in showers). Apart from these expensive measures and adaptations, simple handgrips can improve the accessibility, 
safety, and mobility of older people [10,11]. A further concern that should be considered within the living environment is the lack of storage space for wheeled walkers and mobility scooters (including a place to charge batteries) when living in an apartment block with limited space to manoeuvre in corridors [7].

However, with an increasing demand for care, it is not always possible to remain living in one's own home and moving into a residential or nursing facility is the only remaining option; whereby, nursing care can be provided in these living environments [12]. Policy principles within long-term care also aim to provide a homelike environment for their residents $[13,14]$. Older people should be enabled to continue their lifestyle as before admission to a nursing home.

With the increase and popular notion of the role real estate plays in ageing-in-place and living well in old age, there is also a shifting focus on participation, activation, and helping each other. Today's so-called participation society requires people to look after one another, instead of being solely dependent on a state-run system of healthcare.

Home modifications and the home environment itself have a profound influence on the care given and received at home. In short, the fewer barriers there are at home, the easier and less burdensome family care can be [15]. Family carers themselves need such environmental interventions that support care, and a sense of community and belonging. Enabling one to age-in-place requires more than a simple occupational therapeutic approach of environmental interventions. It requires innovative new housing arrangements that facilitate and enable older adults to live comfortably into old age, preferably with others.

In the following paragraphs, innovative examples are provided from a Dutch social housing association. It illustrates a new approach to environmental design that focuses more on building new communities in conjunction with the building itself, as opposed to the occupational therapeutic approaches and environmental support.

\section{The Changing Role of Social Housing Associations}

The Netherlands has a long and historical tradition of social housing, encapsulating social housing associations which provide housing to people with limited financial resources. There are approximately 360 social housing associations in The Netherlands, which own and maintain approximately 2.4 million housing units [16]. Moreover, a niche in the domain of social housing is formed by real estate encompassing residential houses and nursing care facilities for older people and people who require a high demand for care [12]. The Dutch Government aims to enable people to live at home for as long as possible and reduce the number of people living in institutions. There are several rationales which include the maintenance of one's autonomy, independence, a sense of identity, and quality of life [9]. As a consequence, Dutch social housing associations, which have a large number of institutional facilities within their portfolios, are now facing a growing risk of vacant real estate and associated financial losses. Given the ageing of society, there is the possibility that these vacant buildings may be able to play a role in the current and future housing needs of older people. Outdated real estate may be given a new lease of life, encapsulating new initiatives which are needed to re-use these buildings.

The Dutch social housing association Habion is proactively working to rejuvenate existing buildings and their communities; not through closure or demolition, but by giving these buildings a second lease on life [17,18]. Habion specialises in housing for older people in need of care and support services. Habion aims to ensure the 'good life' and a positive atmosphere for their older residents, even when support and care is needed and becomes necessary [19]. The ethos of Habion is to ensure, through team work and communication with local providers of healthcare, a continuum of housing and health/home care can be delivered to the residents $[17,18]$.

A unique feature of Habion and their strategy is their aim to focus across the different levels of the Maslow hierarchy of needs [20]. The majority of Dutch social housing associations generally focus on the two bottom levels of the pyramid, while having an ambition to also cover the third level (Figure 1). However, Habion wishes to cover all the levels of the pyramid in order to ensure all older residents 
are supported to live a full life in a comfortable environment and where one feels at home [8,21-23]. Habion also aims to ensure their residents can live an autonomous life coupled with the physical space within the respective building(s) there is the opportunity to use the communal meeting space to facilitate spontaneous meetings, activities, and gatherings. These meeting spaces are essential elements in being able to live a meaningful life [24]. Ideally, the basis of the Maslow pyramid, namely the first two bottom levels, should be covered. These levels describe a dwelling of good quality according to the residents, which is clean and well-maintained, which offers an adequate service level and provides residents with a sense of safety and security. This is the basis for further expansion towards the top of the pyramid. Habion aims to achieve this by focusing on (future) residents, as well as the local communities. Habion believes a home is more than just a house and believes in the personal experience and the emotions of all its residents. However, this type of environment does not occur over night but gradually over time, developed by the person or people who deem independence, security, and their self-identity, choice and memories are essential [8,21-27]. The development of a sense of home is associated to the concept of place attachment theory. Place attachment is a multi-dimensional phenomenon that describes the emotional bond between people and place, which is influenced by one's personal experiences [28]. By inviting the local community to join the residents whether they are frail or not, builds upon the concept of place attachment theory. Ensuring there is a bond between all interested parties and making an environment that all would want to be a part of.

\section{A home is more than a house}

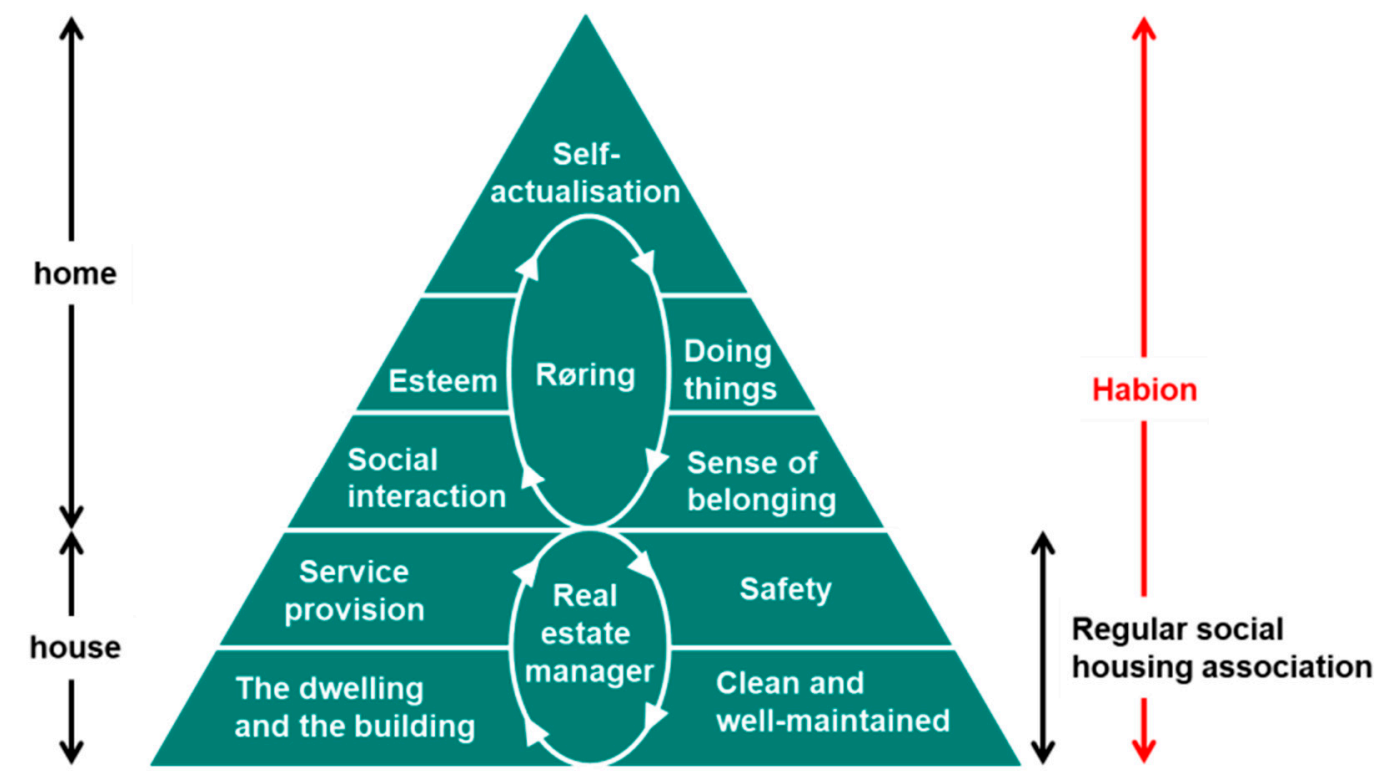

Figure 1. Maslow's hierarchy of needs, represented as a pyramid, adjusted for the mission statement of Habion [19].

In 2017, Habion undertook six transformation projects relating to former aged-care facilities, which have been transformed into new living communities for older and younger residents [19]. Within these buildings, the existing amenities for the provision of healthcare are still conducted but the quality of housing, community ethos, and communal living aim to prevail over an institutional model of care. This means that old real estate is re-used and retrofitted, which includes the installation of new building services throughout the premises. This undertaking forms part of the sustainability strategy which is referred to within the associations' mission statement [19]. Across the Dutch care sector, there is an average of 30-40 years functional life expectancy for all buildings, and once a building has reached it is usually deemed to be unfit and disposed of resulting in the building been demolished. 
In the world of real estate, flexibility in terms of square metres and adaptability of buildings is a key priority. This in turn, leads to a continuous cycle of retrofitting. But the process of retrofitting is costly and coupled with additional issues including increased hindrance and stress (i.e., emotional, physical, or mental) to the residents. Future development should consider a flexible design which allows for flexibility within a building with affordable rents, resulting in an environment where residents can live knowing that they will be able to receive support, assistance and care when in time. Furthermore, the respective building should also accommodate the increasing need for assistance and care (including nursing home care). When someone's living condition changes over time, they can stay living in their current home, and only the rental contract is changed to accommodate for a change in care and support services (Figure 2). The transformation of existing real estate means, first and foremost, the notion of change in the use of the building and its ownership, instead of a costly investment in the structure of the building itself. The basis for these transformations is the concept of living, not the provision of healthcare.
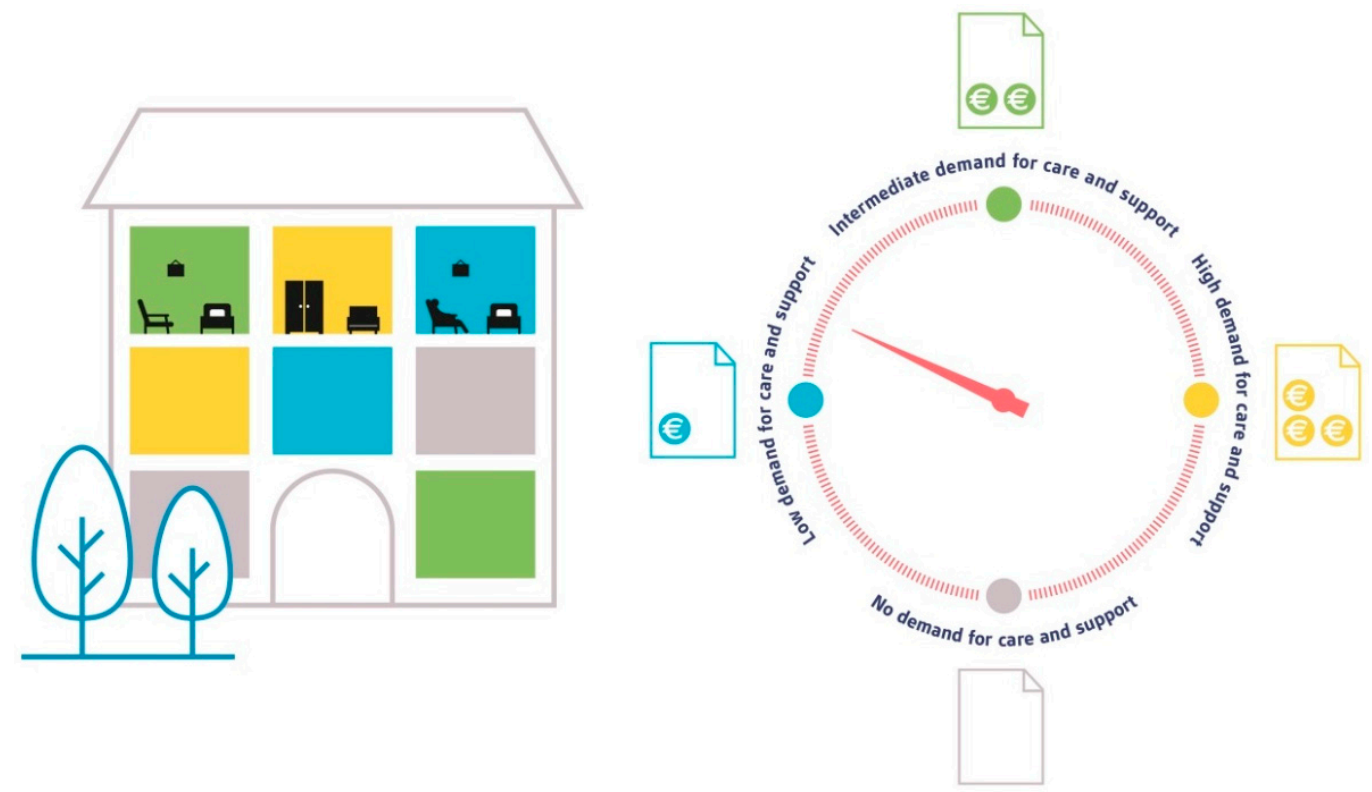

Figure 2. A single building can house multiple tenants who use various care arrangements (types of care, and funded through different financial schemes). Apartments that become vacant can be occupied again by any type of tenant, without the need for retrofitting. Residents can remain living in the apartment, but may be given a new rental contracts, which come at different price levels depending on the service provision level.

\section{Second Youth Experiments: Rationale and Procedure}

In 2010, there were approximately 158,000 residential care and nursing home facilities across The Netherlands, while the total number of people aged 80 years and over was 650,000 and is rapidly increasing [29]. In 2013, the consultancy bureau Berenschot had forecast the demolition of approximately 800 residential care facilities in The Netherlands [30]. Yet, in 2017 there were approximately 100,000 residential care and nursing home facilities left for over 700,000 Dutch people above the age of 80 . Therefore, demolition was neither a realistic nor a viable option. The vacant real estate had to be reinvested to accommodate for the increasing number of older people in search for a place to live. Moreover, demolition is not a sustainable option, because it leads to a waste of materials, a loss of affordable housing and a loss of capital. In collaboration with (future) residents, partners in healthcare, associations, and organisations focusing on sheltered employment, and the local community, Habion develops and redevelops its real estate portfolio which has aimed to ascertain and understand the needs and requirements of older adults. 
Currently, Habion is involved in several transformation projects with various local partner organisations. Across each location there are separate and individual opportunities and differences in culture. Therefore, it is impossible to provide a unique blueprint for understanding and implementing this transformation process. Every transformation project has to start from scratch, although experiences from previous transformation projects are considered as there are some returning themes that are shared by residents. Such transformation processes are rather iterative, and that is why Habion has tried to turn the experiences of the past five years into a methodology coined 'Røring' (based on the Dutch word reuring, which means bustle, commotion, or buzz) [17,31,32]. The methodology enables the creation of a plan and to commence transformations within a one-year period.

Røring is a sequential methodology which involves a kick off meeting to facilitate and inspire participants, in workshops leading to and data analyses, translating to a greater understanding of the needs and requirements which in turn will be integrated in the implementation phase, followed by a formal evaluation. Throughout each phase, feedback will be required from residents in a bid to stimulate the 'life and soul' of the process (Figure 3). It is important to the process that all current and future residents are at the forefront of these plans and discussions, which, in turn, enables future or existing residents to express their thoughts, views, and opinions. All existing and prospective residents need to be supportive of any plans, in conjunction with participating care and welfare organisations, which in turn, will enable the support, a commitment for a new attitude and culture within the physical space.

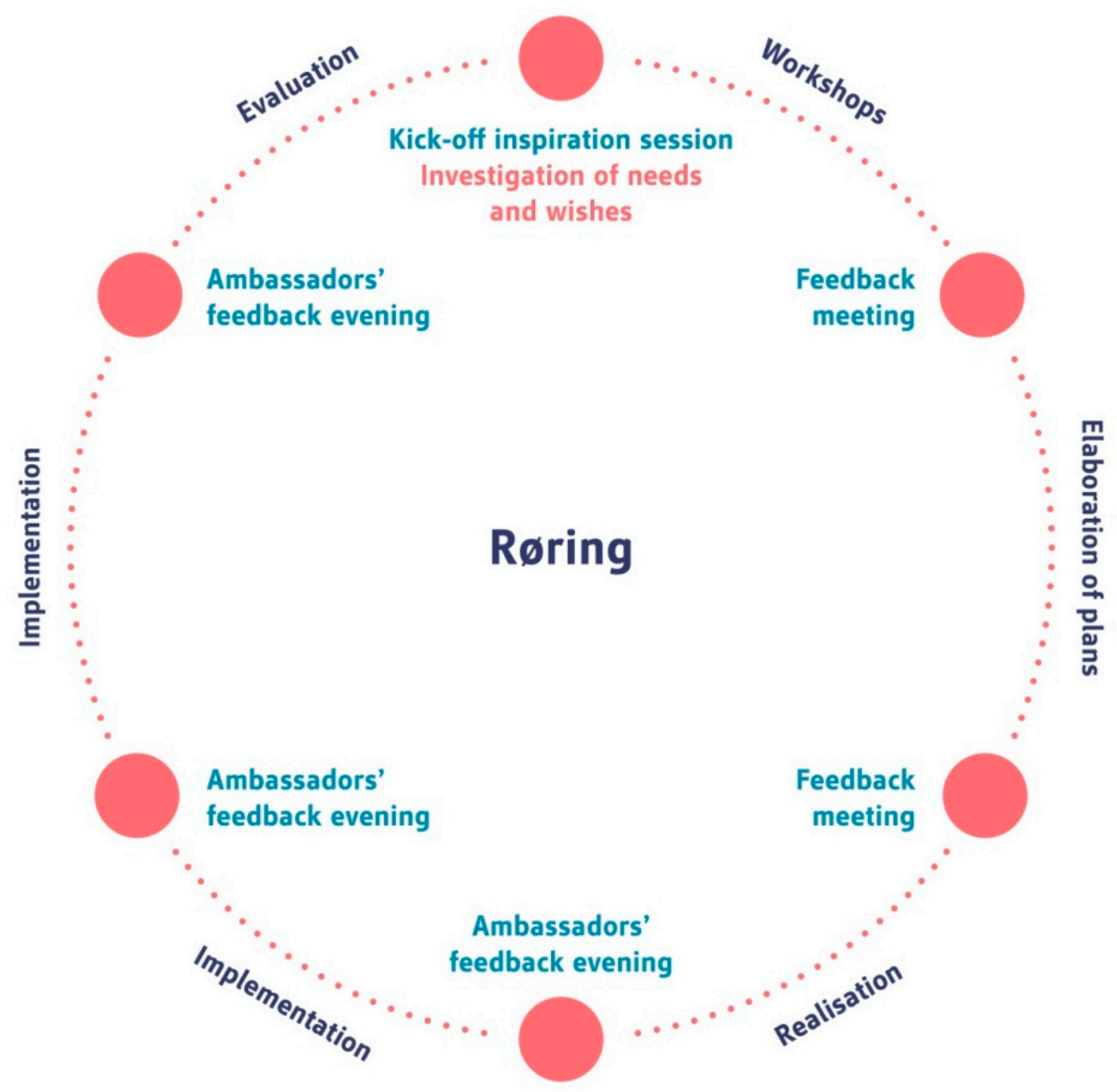

Figure 3. The cycle of the Røring methodology as applied in Second Youth projects [19]. 
Enabling local communities to have the opportunity and the ability to reinvent their social housing enables the communities to have a sense of self-acknowledgement, self-respect, self-worth, and overall engagement and communication with interested parties, who all share the same ethos and beliefs of enjoying a good life in later life. The transformation makes it much easier for the occupants, society and Habion to grant new providers and partners a license to operate in the building.

\section{De Benring Case Study}

In November 2013, the residential care facility De Benring (Figure 4) in Voorst (a small village with approximately 2750 inhabitants in the Dutch Province of Gelderland), which had been in use since 1971, was identified for demolition. This decision was based upon the diminishing demand for this type of housing in conjunction with the change in government policies; which called for the closure of this type of housing and care. The local care institution wanted to end the lease of the contract and relocate the residents to alternative care facilities. This resulted in an advertisement via a public billboard, which announced the building would be 'demolished'. It was the trigger for over 400 people to stand up and speak out, explaining why it was important that De Benring residential care facility should remain as an integral part of the town's community.

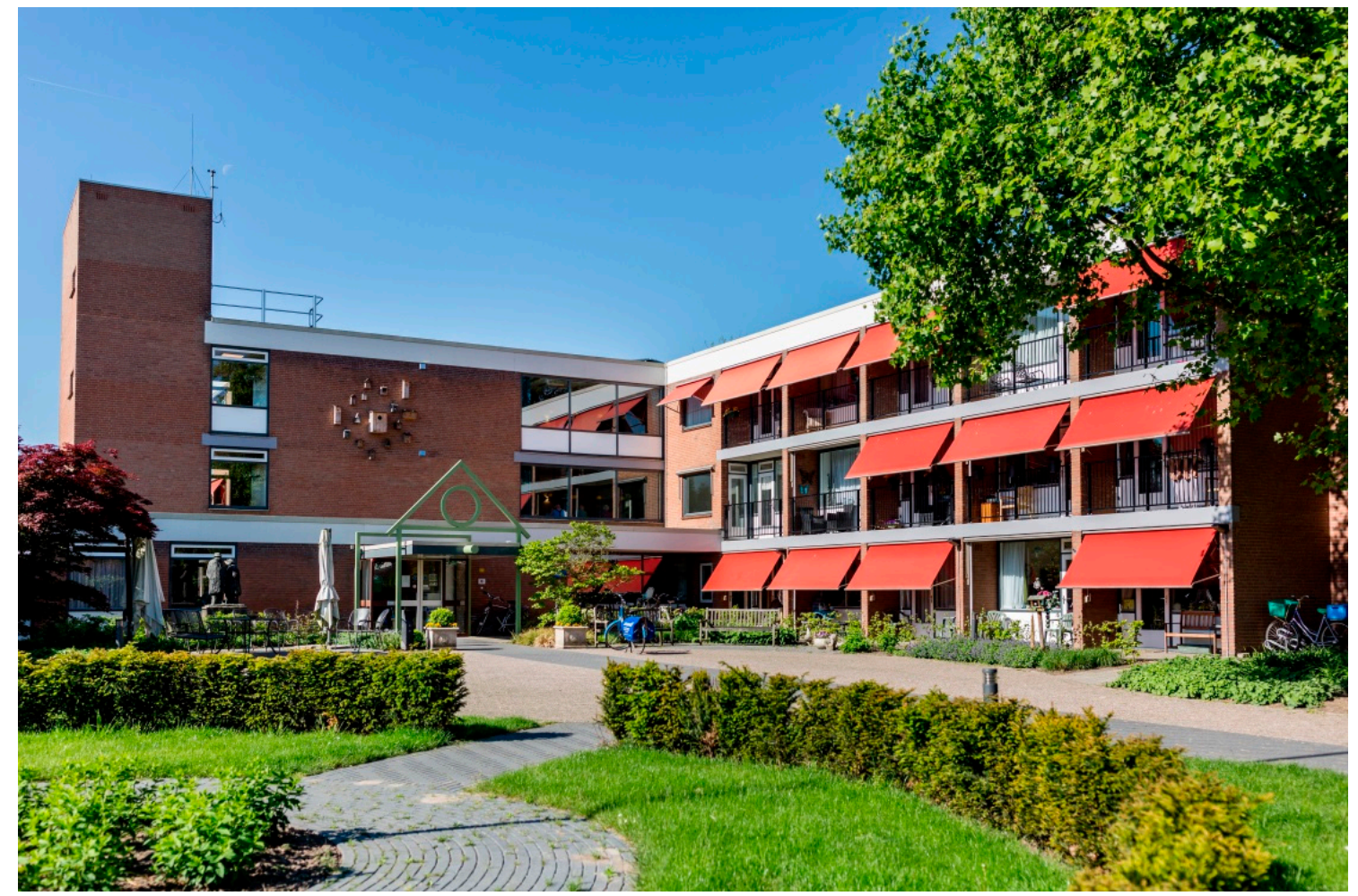

Figure 4. View of the premises.

The original building itself had a gross floor area of $5824 \mathrm{~m}^{2}$ spread over three floors. There were 96 units for habitation, for a number of 102 residents, including 80 units that were rented by an organization providing domestic care for 86 residents, and 16 units that were rented by an organization providing care for people with a mental disability. In addition, the building itself included rooms for recreation, a laundry area, offices, a small shop and a hair salon. There are an additional 18 attached accommodations for older people. In the old situation, clients of both care organisations lived in a separate wing. The older clients of the first organisation live in their own apartment, and meals and other provisions were arranged by the central organisation. The clients with a mental disability lived 
in small-scale group units, where they cooked and did laundry under supervision. They had access to their own kitchen area, a mutual living space and their own entrance.

The call for demolition resulted in the villagers to be challenged by the government to take ownership of the building and to express their own dreams and expectations in a co-creation workshop. This resulted in more than 1000 wishes that were shared by the participants in a workshop following the Røring method.

Several perceptions were shared across these workshops and included:

- greater involvement from the community $(\sim 65 \%)$;

- greater privacy and independence $(\sim 20 \%)$;

- wishes concerning diversity in population (intergenerational population, socio-cultural differences) $(\sim 15 \%)$;

- $\quad$ residents noted the need for affordable housing ( $75 \%)$; and

- the adequate provision of care $(\sim 55 \%)$.

By taking full responsibility for future functionalities of the building and its prospective future residents, the local community literally 'stepped into' the building. Their needs and wishes were translated into a programme for the transformed building, and the wish for greater involvement of the community was granted and facilitated. While, the institutional partners 'stepped out', they still continued to facilitate the transition process which enabled the transformation of the building to take place and the expectations of the residents' dreams were implemented. De Benring was officially opened in October 2016 and today the institutional partners only provide the services that are required by the residents, such as home care.

The transformed De Benring is made up of various components (Figure 5). Older people live in the former main wing, and some of the rooms are merged, and a number of bathrooms are enlarged. This was directed at improving independence and privacy. The number of apartment units was reduced to a total of 74, of which 38 are occupied by older people, and 24 by people with a mental disability, eight for group living, and four for temporary residence.

Within De Benring, there are several residential groups encompassing different age ranges. In the original situation, prior to the transformation of De Benring, there were 18 attached accommodations dwelled by independent older people in need for surveillance and some domestic care. These attached accommodations were renovated in 2014 and are now occupied by younger people up to the age of approximately 22 years (Figure 6). These younger people got the assignment to conduct do-it-yourself activities to make the apartments habitable again. The wish to live together with different generations under one roof was facilitated this way. This contributes to a multi-generational mix of tenants, who are able to provide a positive living approach while learning from one another and in some instances helping one another. On average, about $90 \%$ of the tenants are older people (at least 55 years old, but in most case aged 80 years and over), and about $10 \%$ are more vital and young tenants. These younger tenants have to take a test to see if they match with the goals to live together with different age groups, and, for instance, if they would be a suitable candidate for a so-called buddy partnership with a co-resident. 


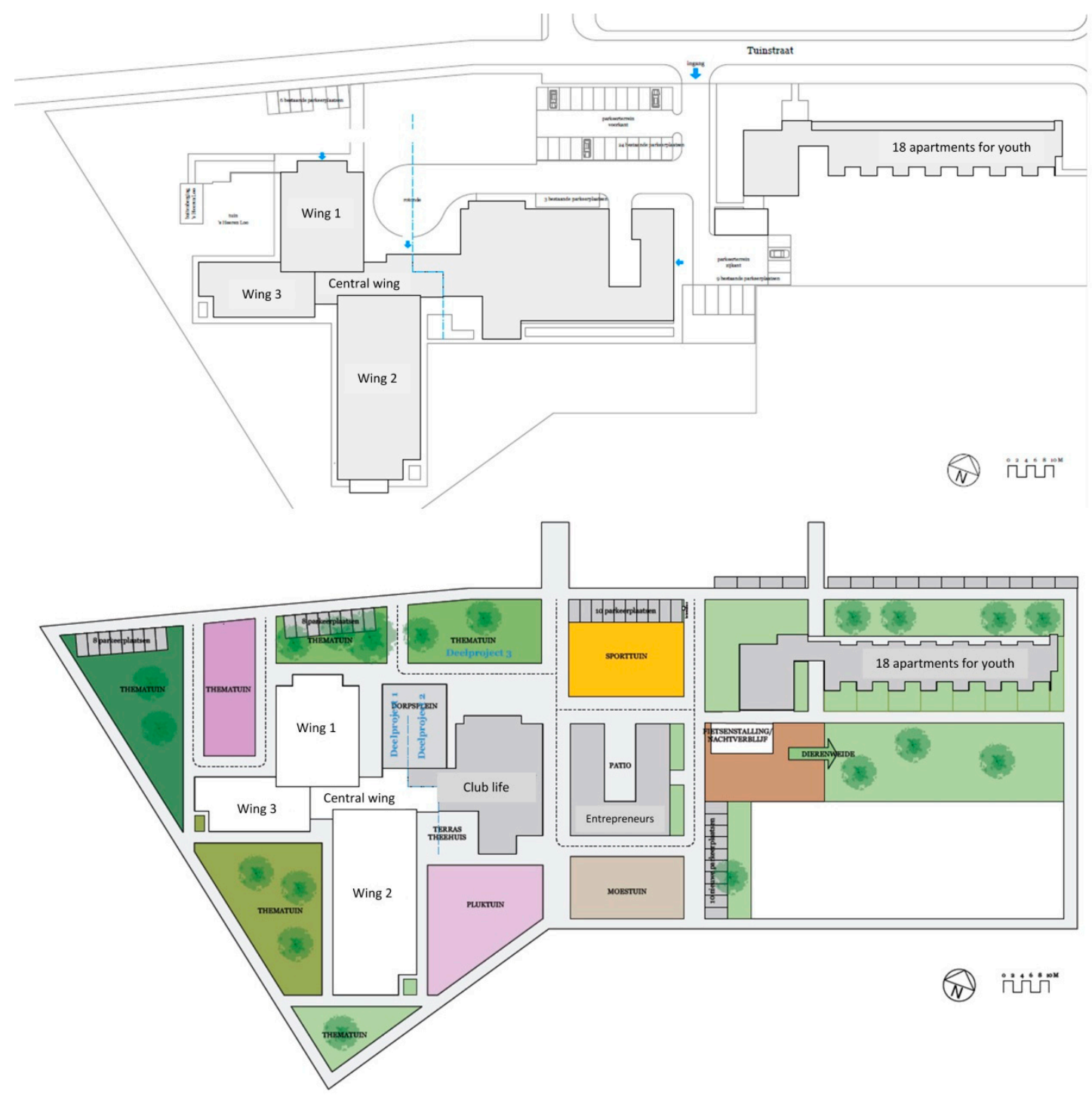

Figure 5. Overview of the masterplan for De Benring: before and after.

The residents requested to have a mix of different functionalities available and easily accessible under one roof, for instance, being able to cook together in a communal kitchen area (Figure 7), meeting others in a shared living room, or shop together in a commercial second-hand in De Benring (Figure 8). Some of the apartments are even used as bed \& breakfast facilities and are run by the community. The hallways were transformed into extended living or communal areas which support the vitality of the entire community (Figure 7). This extension has enabled greater social inclusion by the villagers and residents relating to cooking and social activities. The tenants have their own shared fireplace, where they can meet fellow residents, sit together and have a talk. This is one of the measures to improve the need to meet other residents and stimulate interaction and engagement. 


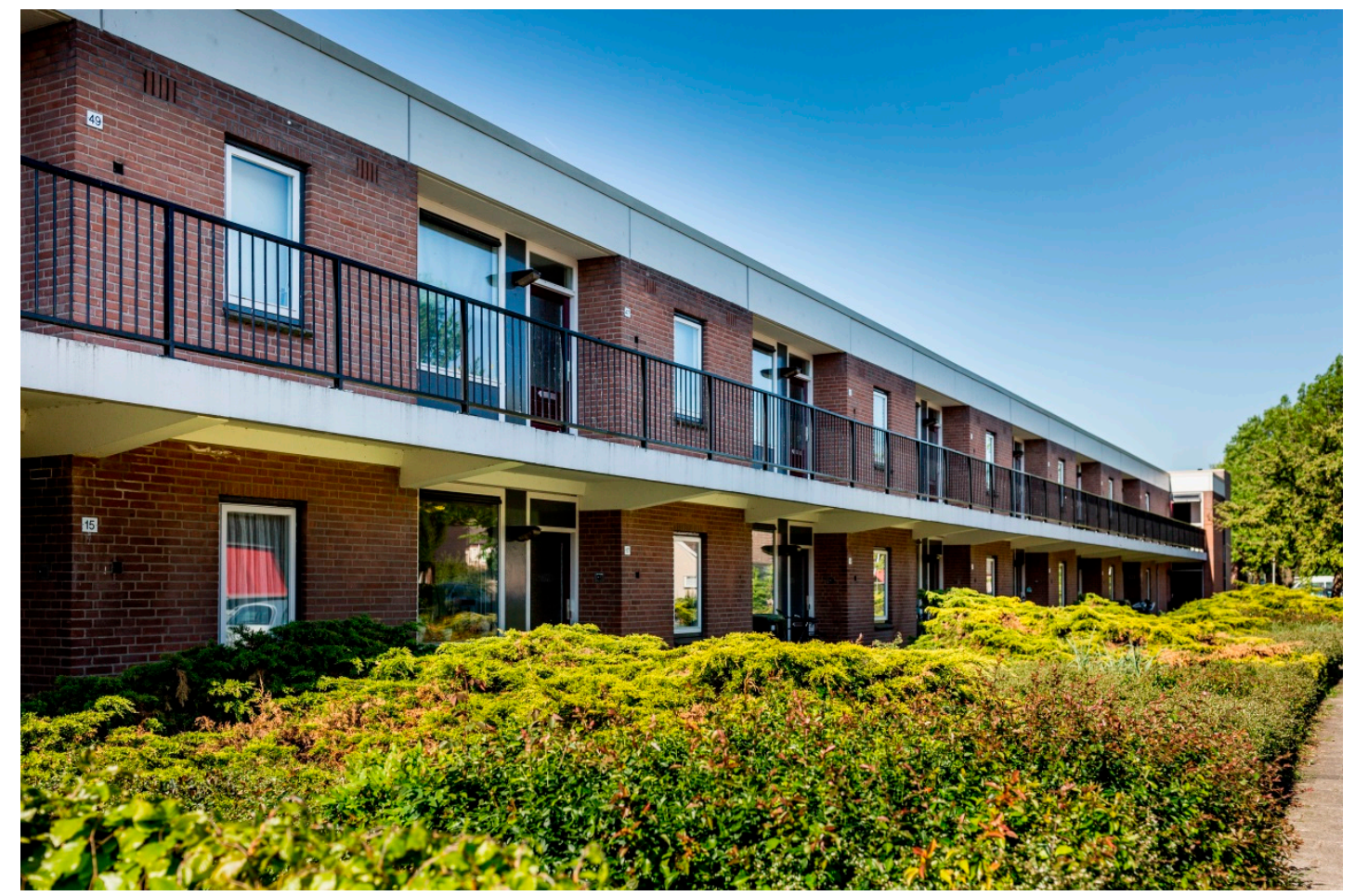

Figure 6. The wing with housing units for younger tenants.

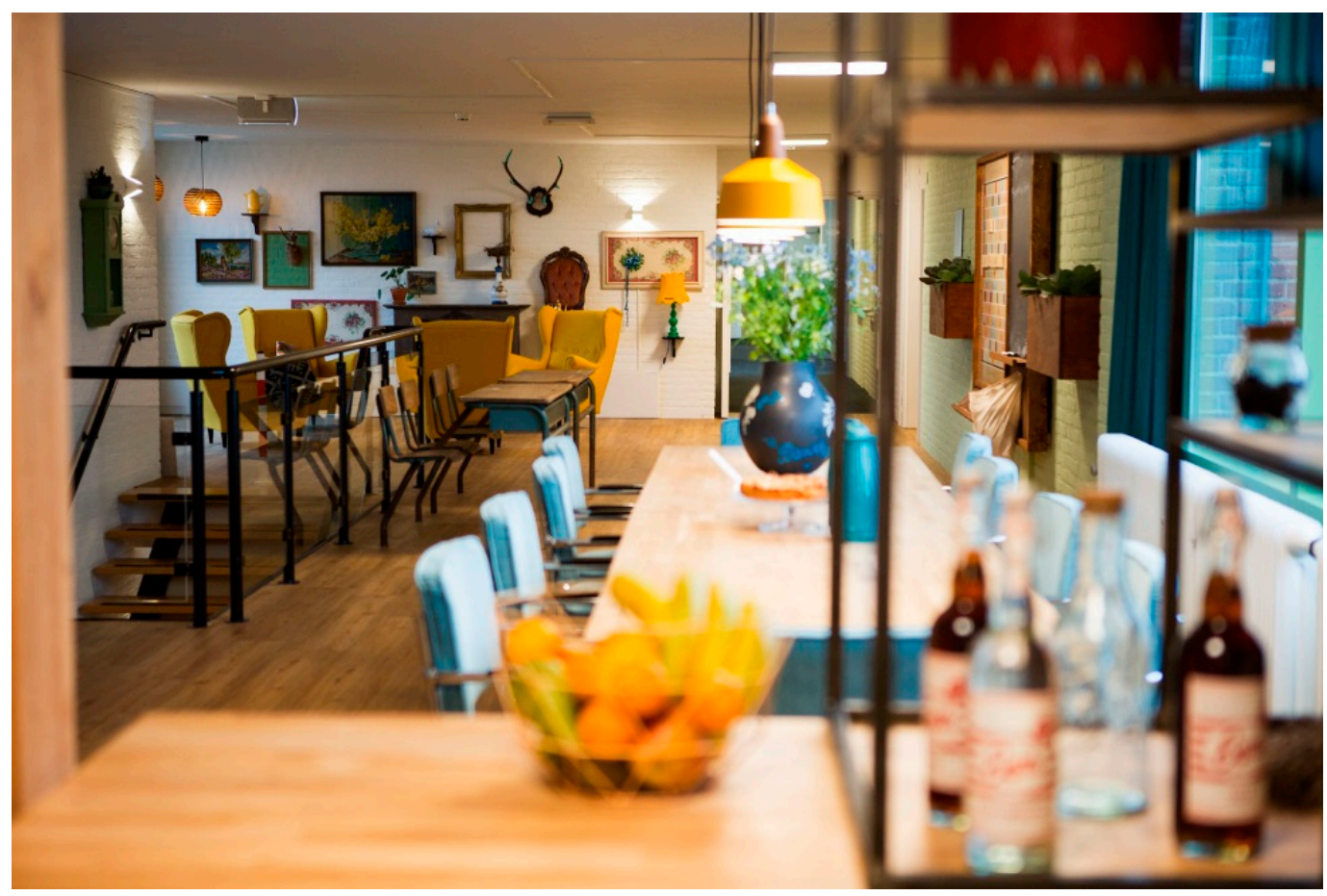

Figure 7. A view of a communal kitchen area and living room. 


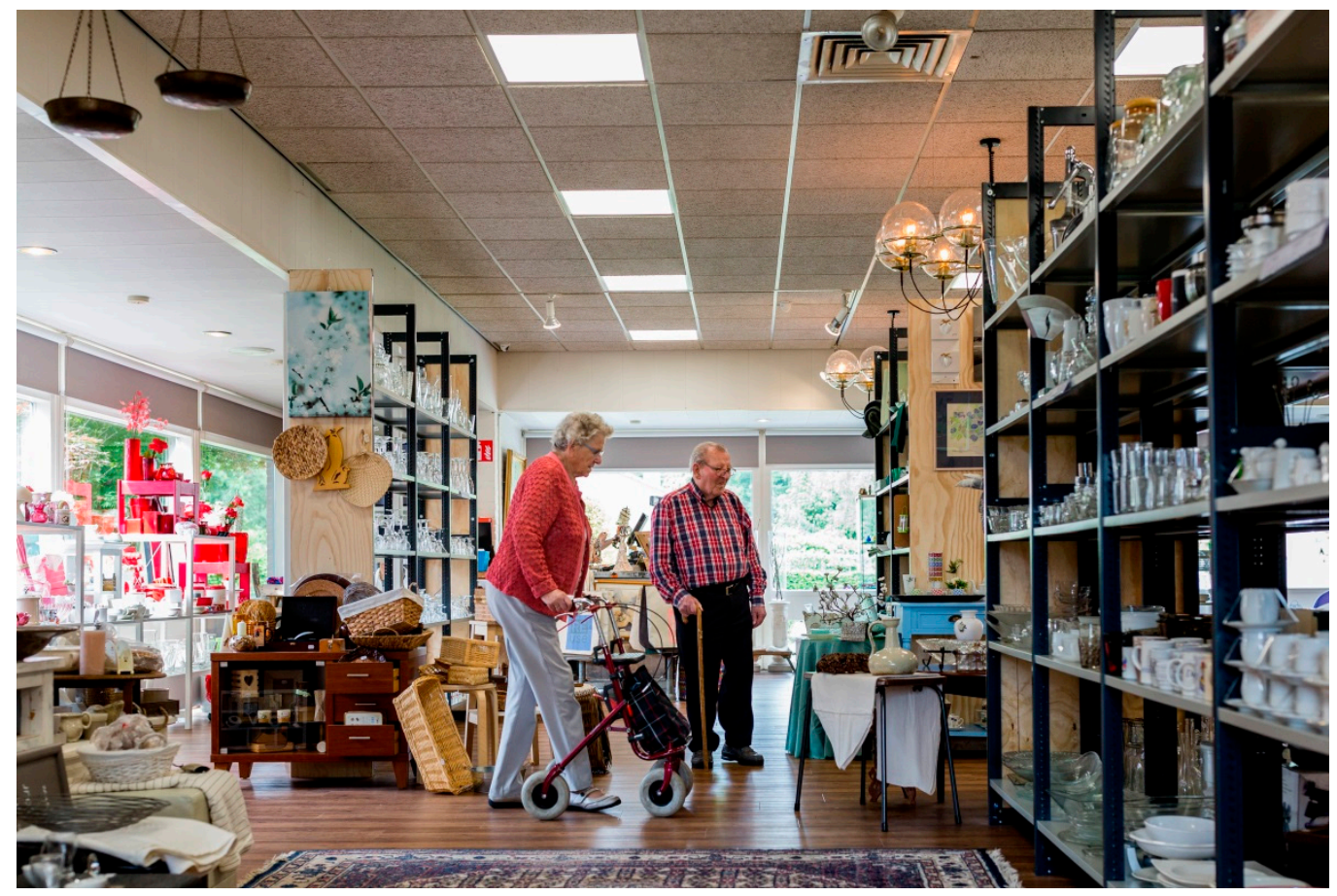

Figure 8. The new second-hand shop inside De Benring.

The former recreational space, kitchen and living areas were connected, which is supposed to draw in village life. In addition, there are commercial spaces that can be rented to social entrepreneurs (Figure 8).

Moreover, every apartment in De Benring can facilitate the provision of any kind of healthcare (i.e., domestic care, nursing home care, and care for people with a mental disability), whereas in The Netherlands such types of residential healthcare are segregated. Yet, all apartments can either be used as a residential or nursing care unit/dwelling enabling multiple residents and target populations inclusivity. This concept and flexible transition (if required) ensures that care and housing are future-proof against changes in government policies.

In order to transform the old De Benring premises into a new community building, some changes were made to the floorplans (Figure 9). These changes were made in order to improve the independence and privacy of the residents, and make rooms more supportive for older people. Some of the measures were put in place in order to comply with Dutch building codes and standards for retrofitting existing real estate.

All bathrooms were fully renovated and enlarged, and equipped with sliding doors. These sliding doors are easier to pass with a wheeled walked or when seated in a wheel chair, and increase the usable space of a room. Most of the apartments were merged, by making a passage way in the load-bearing concrete partition walls (Figure 10). This led to an increase in surface area of $23-24 \mathrm{~m}^{2}$ to $46-48 \mathrm{~m}^{2}$ per apartment. The own apartment thus became larger and offers more privacy to its occupants. More structural interventions were conducted in the meeting areas, and an additional entrance was made to allow people from the adjacent neighbourhood to enter the building to use the activity rooms, second-hand shop, day-care organisation, and offices. 


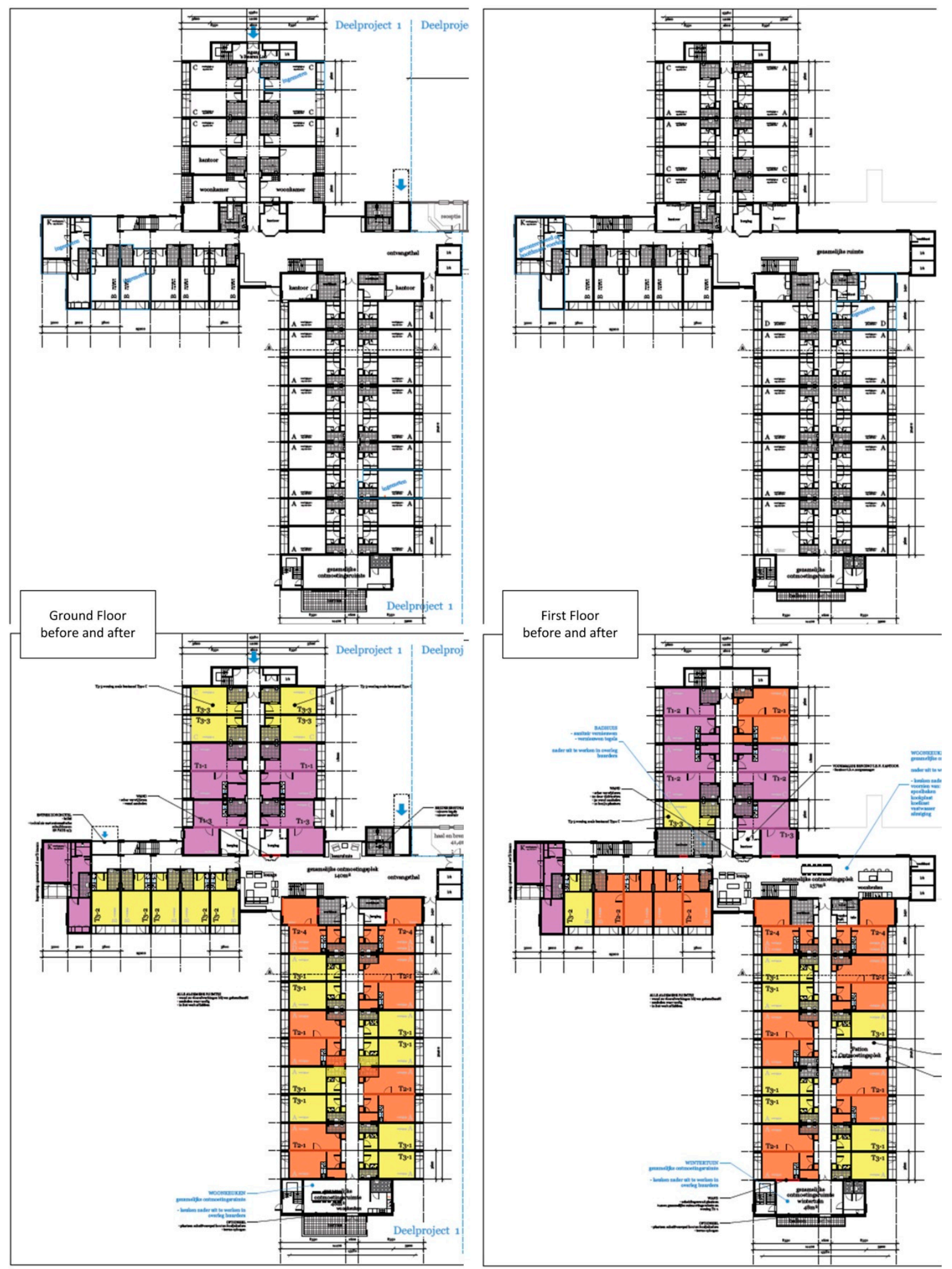

Figure 9. Plans of ground and first floors; before and after the transformation. Extensive merging of apartments was conducted in order to make them larger. 

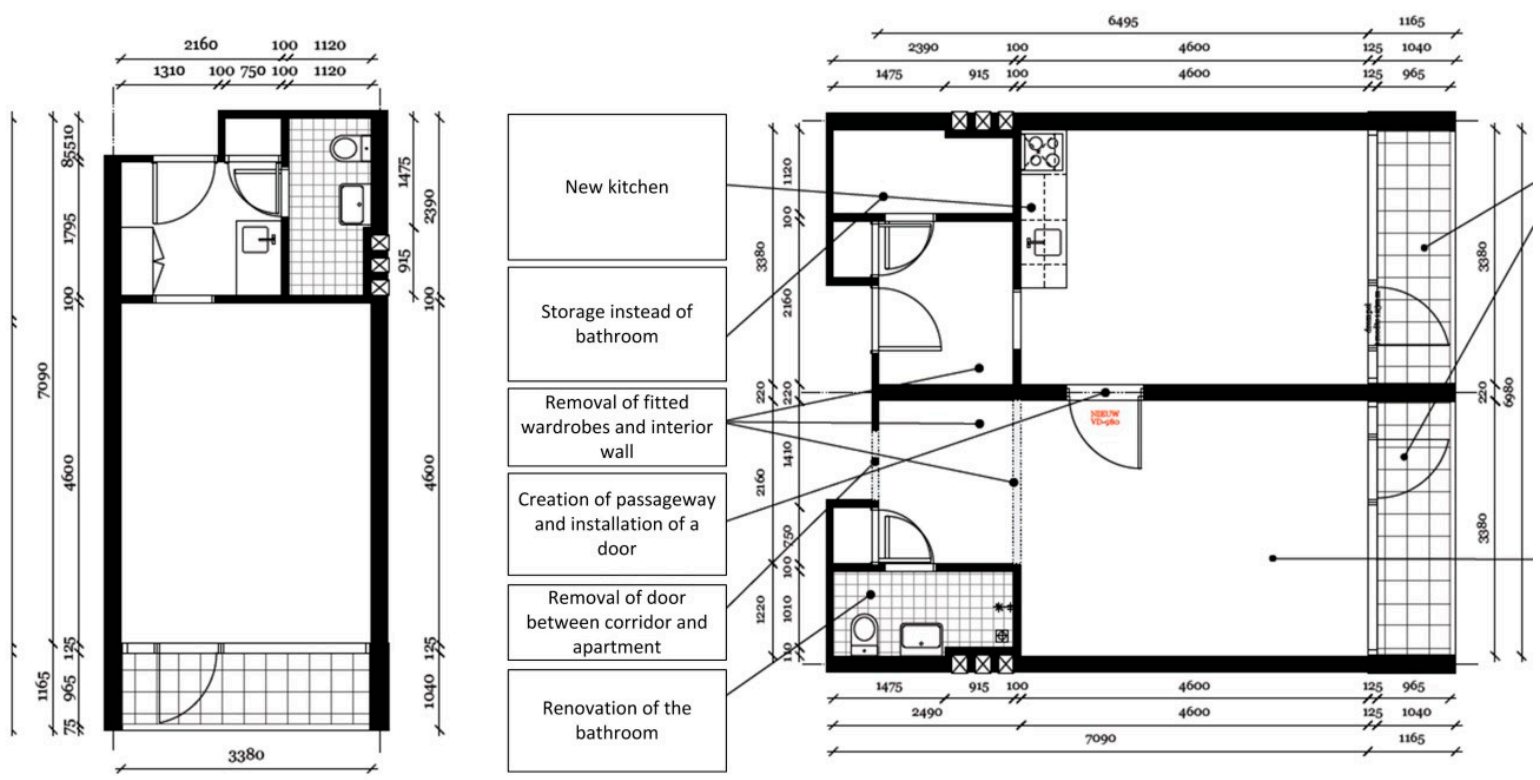

Figure 10. Floor plan of apartment in the old situation, and after the merging of two apartments and their renovation works.

Some of the apartments were removed in order to improve daylight access on the long corridors. Group living was realised on the lower floors because of accessibility requirements; there is no need to use an elevator or climb stairs. All balconies of the building were renovated, which included the replacement of fences and railings, and coating of the floors. The façades of the building were renovated, including painting the wooden parts of the façade, renovation of the pointing and masonry, and replacement of the roofing. All asbestos was removed throughout the premises.

All units for independent living were equipped with small kitchens and cooker tops (Figure 10). In shared living spaces, a group kitchen with modern equipment was installed (Figures 7 and 11). Finally, the interior design and furniture was addressed and totally replaced.

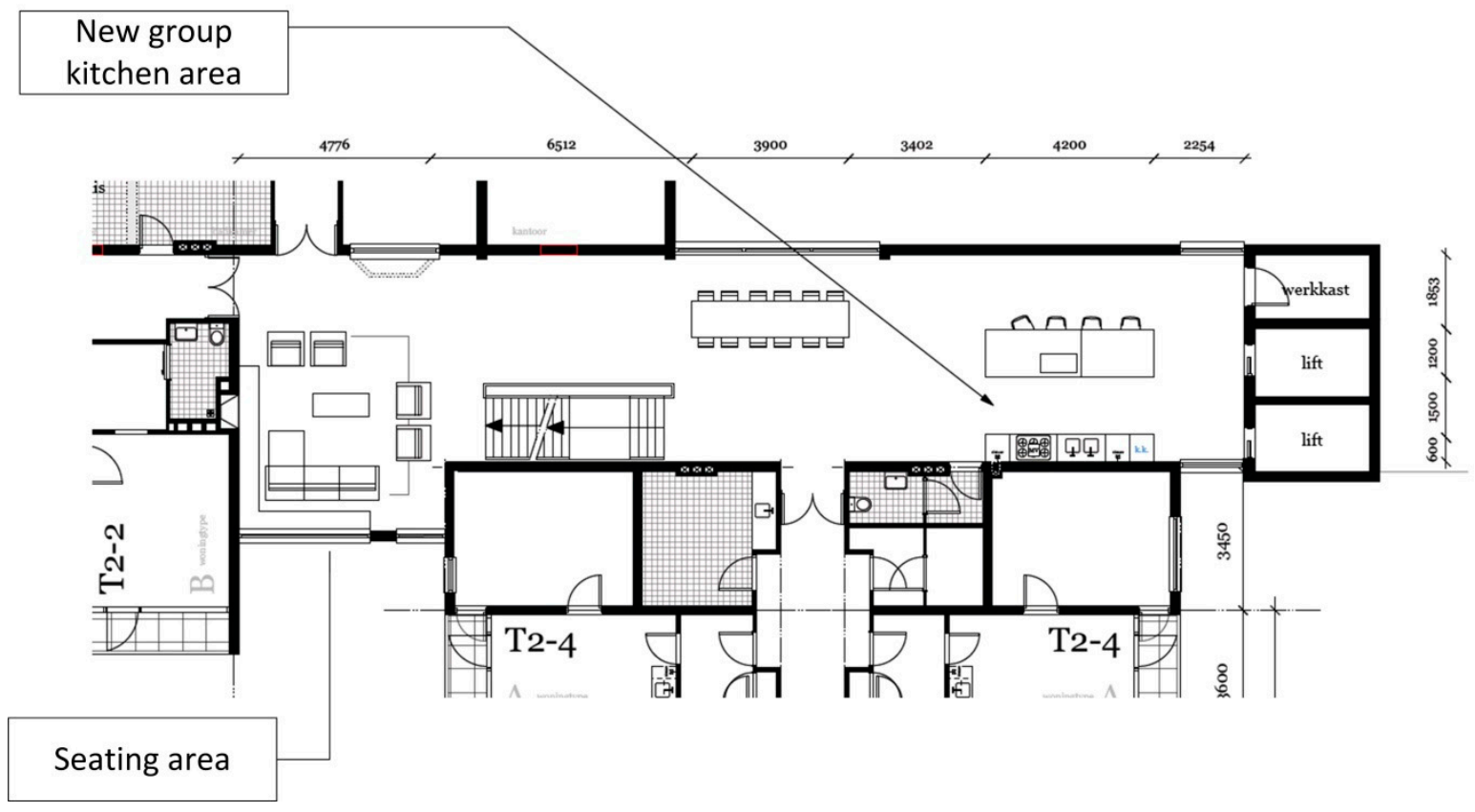

Figure 11. New group kitchen and seating areas on first and second floors. 
In terms of the building services, a large number of measures were carried out as well. All electrical installations were replaced in compliance with the NEN 1010:2015 nl standard [33]. The former ventilation system was based on natural ventilation. In the renewed building, a system for mechanical ventilation was installed in the apartments and communal spaces. All the drinking water installations were replaced in order to meet national requirements for drinking water safety and prevent the growth of Legionella bacteria. The stand pipes of the sewage systems were replaced throughout the building. Existing elevator cabins were reused and renovated. The residents had a dream to live a sustainable lifestyle. This was made possible via a crowdfunding initiative encompassing 512 solar panels that were installed on to the roof [18]. This installation was another wish of the residents that was granted (Figure 12). The most significant intervention was the renovation of the central heating system, in which the two existing heating units were replaced by two collective heaters for the total premises. These heaters were placed on the second floor in two newly created spaces, which were supported by a new load-bearing steal frame.

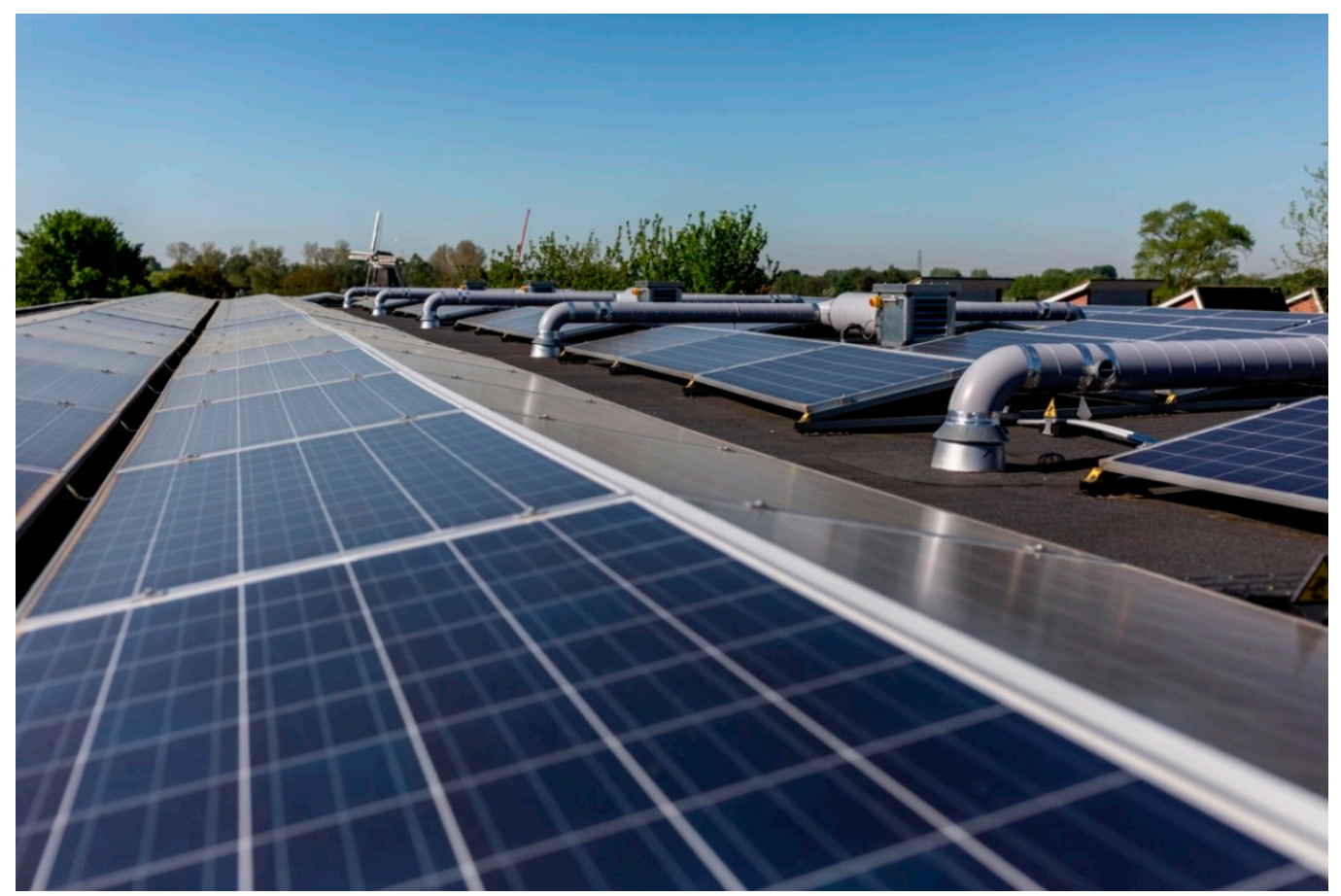

Figure 12. View of the solar panels.

In addition to these energy-saving measures, the energy labels of the premises were improved. Prior to the transformation, no energy label data were available as the apartments were not classified as independent units for occupancy, and given the plans for demolition, De Benring was not certified using the Dutch EPA-U methodology (Energie Prestatie Advies Utiliteit Energy Performance Certification for Utility Buildings). After the transformation (date of certification: 20 February 2018), 45\% of the apartments are Label A $(n=33), 18 \%$ are Label $B(n=13)$, and $38 \%$ are Label C $(n=28)$ (Energy Index <1.20 for Label A; Energy Index 1.21-1.40 for Label B; and Energy Index 1.41-1.80 for Label C). This is an improvement in comparison with the old situation with a predicted Label ranging between $\mathrm{D}$ and $\mathrm{F}$ (Energy Index between 1.81 and 2.70).

When taking into account the safety regulations (i.e., fire regulations), this concept can make things more difficult for the fire services to cooperate and communicate with. This is because there is an increase risk in false alarms, especially if the place is no longer a single care residence but a cluster of independent apartments. The building is equipped with so-called smart fire control units which culminate in double detection (at least two sensors in one dwelling) which if in case of an 
emergency, the alarm will send out an alert to the fire station in order to prevent false alarms from occurring. Examples of false alarms include the steam produced by cooking or showering activities. In the renewed De Benring building, all main and sub-compartments were equipped with materials and measures that comply with the latest fire requirements.

Finally, the outdoor space was redesigned, including the outdoor lighting and sewage systems. Existing parking facilities were extended, and finally, a new gardening plan was executed (Figure 5).

\section{Conclusions}

The ageing of the population in The Netherlands and neighbouring countries leads to a shift in the demand for housing. As older people are encouraged to age-in-place, either in their own home or in a larger building with multiple apartments, there is a need for innovative new housing arrangements. In The Netherlands, social housing associations play an important role in providing such type of housing. At the same time, some of the existing real estate which makes up a substantial part of the portfolio of a housing association may not be suitable to accommodate the wishes and needs of older people. Such wishes include being part of a community apart from living in a building that is accessible, safe and secure, as well as supportive. Social housing association Habion, therefore, undertakes transformation projects, which are referred to as "Second Youth Experiments". The concept of re-inventing existing real estate concerns a positive notion of co-creating housing within the occupants of a building and the community as a whole, even when health, nursing and social care is needed. The focus is on the quality of living and housing, and less on the demand for care, and, therefore, the tenants are in control of the future direction the building itself and the way it is run are heading. The approach provides an opportunity to create additional value and affordable housing for older people who may be financially restricted to renting property based on their financial situation. By ensuring the trust to local communities and giving them the lead and voice to express how they perceive their future living environments through the Røring methodology, an active stakeholder participation can be stimulated. The re-invention of existing real estate can improve the sense of community and at the same time contribute to achieving sustainability goals, as the building itself is no longer demolished after 40 years of exploitation, but is given a second life instead. The case study of De Benring showed how social and technological innovations can be integrated in the retrofitting of existing real estate for older people. Such an approach leads to a flexible use of renewed real estate, which makes the retrofitted building system- and customer preference proof.

Author Contributions: Conceptualisation, J.v.H. and P.B.; writing, J.v.H.

Funding: This research received no external funding.

Acknowledgments: Joost Maas of Vastgoed Zorgsector is thanked for the photography and images, and Danny de Vries of Vastgoed Zorgsector is thanked for his role in providing practical data from his role as project leader. The Chair of Urban Ageing of The Hague University of Applied Sciences has financed the open access fees of this publication. Architectural floor plans were commissioned by Habion and made by Fact Architects, Amsterdam, The Netherlands.

Conflicts of Interest: At the time of writing, Joost van Hoof was the vice-president of the board of Vastgoed Zorgsector, and the vice-president of the supervisory board of Habion.

\section{References}

1. Michael, Y.L.; Green, M.K.; Farquhar, S.A. Neighborhood design and active aging. Health Place 2006, 12, 734-740. [CrossRef] [PubMed]

2. Buffel, T.; Phillipson, C. Can global cities be 'age-friendly cities'? Urban development and ageing populations. Cities 2016, 55, 94-100. [CrossRef]

3. Van Bronswijk, J.E.H.M. Healthy housing for active aging. Gerontechnology 2015, 14, 187-191. [CrossRef]

4. Kort, H.S.M. Healthy building environments for ageing adults. Gerontechnology 2017, 16, 207-210. [CrossRef]

5. Van Hoof, J.; Kazak, J.K. Urban Ageing. Indoor Built Environ. 2018, 27, 583-586. [CrossRef] 
6. Kuboshima, Y.; McIntosh, J.; Thomas, G. The design of local-authority rental housing for the elderly that improves their quality of life. Buildings 2018, 8, 71. [CrossRef]

7. Kazak, J.; van Hoof, J.; Świąder, M.; Szewrański, S. Real estate for the ageing society-The perspective of a new market. Real Estate Manag. Valuat. 2017, 25, 13-24. [CrossRef]

8. Van Hoof, J.; Verbeek, H.; Janssen, B.M.; Eijkelenboom, A.; Molony, S.L.; Felix, E.; Nieboer, K.A.; Zwerts-Verhelst, E.J.M.; Sijstermans, J.J.W.M.; Wouters, E.J.M. A three perspective study of the sense of home of nursing home residents: the views of residents, care professionals and relatives. BMC Geriatr. 2016, 16, 169. [CrossRef] [PubMed]

9. Van Hoof, J. Ageing-in-Place: The Integrated Design of Housing Facilities for People with Dementia; Eindhoven University of Technology: Eindhoven, The Netherlands, 2010; ISBN 978-90-386-2326-9.

10. Van Hoof, J.; Kort, H.S.M.; van Waarde, H.; Blom, M.M. Environmental interventions and the design of homes for older adults with dementia: an overview. Am. J. Alzheimer Dis. Other Dement. 2010, 25, $202-232$. [CrossRef] [PubMed]

11. Van Hoof, J.; Blom, M.M.; Post, H.N.A.; Bastein, W.L. Designing a 'think-along dwelling' for people with dementia: A co-creation project between health care and the building services sector. J. Hous. Elderly 2013, 27, 299-332. [CrossRef]

12. Van Hoof, J.; Kort, H.S.M.; van Waarde, H. Housing and care for older adults with dementia: A European perspective. J. Hous. Built Environ. 2009, 24, 369-390. [CrossRef]

13. Moise, P.; Schwarzinger, M.; Um, M.-Y. OECD Health Working Papers no. 13. Dementia Care in 9 OECD Countries: A Comparative Analysis; OECD Publishing: Paris, France, 2004.

14. Verkerk, M.J.; van Hoof, J.; Aarts, S.; de Koning, S.J.M.M.; van der Plaats, J.J. A neurological and philosophical perspective on the design of environments and technology for older people with dementia. J. Enabl. Technol. 2018, 12. [CrossRef]

15. Duijnstee, M.S.H. De Belasting van Familieleden van Dementerenden [The Burden on Relatives of People with Dementia]; Katholieke Universiteit Nijmegen: Nijmegen, The Netherlands, 1992. (In Dutch)

16. Aedes. 2018. Available online: https://www.aedes.nl/feiten-en-cijfers/woning.html (accessed on 2 July 2018). (In Dutch)

17. Boerenfijn, P. Never waste a good crisis: How local communities successfully re-invent aged care facilities in The Netherlands. Gerontechnology 2017, 16, 239-241. [CrossRef]

18. Boerenfijn, P.; Kazak, J.K.; Schellen, L.; van Hoof, J. A multi-case study of innovations in energy performance of social housing for older adults in The Netherlands. Energy Build. 2018, 158, 1762-1769. [CrossRef]

19. Habion. Jaarverslag Stichting Habion 2017 [Annual Report Habion 2017]; Habion: Houten, The Netherlands, 2018. (In Dutch)

20. Maslow, H. A theory of human motivation. Psychol. Rev. 1943, 50, 370-396. [CrossRef]

21. Eijkelenboom, A.; Verbeek, H.; Felix, E.; van Hoof, J. The architectural factors influencing the sense of home in nursing homes: an operationalization for practice. Front. Arch. Res. 2017, 6, 111-122. [CrossRef]

22. Molony, S.L. The meaning of home. A qualitative metasynthesis. Res. Gerontol. Nurs. 2010, 3, $291-307$. [CrossRef] [PubMed]

23. Rijnaard, M.D.; van Hoof, J.; Janssen, B.M.; Verbeek, H.; Pocornie, W.; Eijkelenboom, A.; Beerens, H.C.; Molony, S.L.; Wouters, E.J.M. The factors influencing the sense of home in nursing homes: a systematic review from the perspective of residents. J. Aging Res. 2016, 2016, 6143645. [CrossRef] [PubMed]

24. Felix, E.; de Haan, H.; Vaandrager, L.; Koelen, M. Beyond thresholds: The everyday lived experience of the house by older people. J. Hous. Elderly 2015, 29, 329-347. [CrossRef]

25. Van der Wal, P. Wat Maakt Het Leven de Moeite Waard? [What Makes Life Worth Living?]; Boekencentrum: Utrecht, The Netherlands, 2018; ISBN 978-90-239-5238-1. (In Dutch)

26. Van Hoof, J.; Janssen, M.L.; Heesakkers, C.M.C.; van Kersbergen, W.; Severijns, L.E.J.; Willems, L.A.G.; Marston, H.R.; Janssen, B.M.; Nieboer, M.E. The importance of personal possessions for the development of a sense of home of nursing home residents. J. Hous. Elderly 2016, 30, 35-51. [CrossRef]

27. Wouters, E.J.M.; van Hoof, J. Professionals' views of the sense of home in nursing homes: Findings from LEGO SERIOUS PLAY workshops. Gerontechnology 2017, 16, 211-216. [CrossRef]

28. Scannell, L.; Gifford, R. Defining place attachment: A tripartite organizing framework. J. Environ. Psychol. 2010, 30, 1-10. [CrossRef] 
29. Aedes-Actiz Kenniscentrum Wonen-Zorg. 2018. Available online: https://www.kcwz.nl/thema/cijfers-entrends / kengetallen (accessed on 2 July 2018). (In Dutch)

30. Castelijns, E.; van Kollenburg, A.; te Meerman, W. De Vergrijzing Voorbij. [Beyond the Ageing of Society]; Stichting Fundatie Berenschot: Utrecht, The Netherlands, 2013; ISBN 978-94-90314-15-6. (In Dutch)

31. Maas, J. Een Tweede Jeugd voor De Benring. Een Toekomstvisie voor Ouderenhuisvesting [A Second Youth for De Benring. A Future Vision of Housing for Older People]; Habion: Houten, The Netherlands, 2016. (In Dutch)

32. Maas, J. Een tweede jeugd voor bejaardenhuizen [A second youth for residential care homes]. Gerōn 2017, 19, 41-44. (In Dutch)

33. Standard NEN 1010:2015 nl. Elektrische Installaties voor Laagspanning-Nederlandse Implementatie van de HD-IEC 60364-Reeks [Electrical Installations for Low-Voltage-Dutch Implementation of the HD-IEC 60364-Series]; NEN: Delft, The Netherlands, 2015. (In Dutch)

(C) 2018 by the authors. Licensee MDPI, Basel, Switzerland. This article is an open access article distributed under the terms and conditions of the Creative Commons Attribution (CC BY) license (http://creativecommons.org/licenses/by/4.0/). 